\title{
EFFECT OF DIFFERENT COMPLEMENTARY FEEDING ON IRON DEFICIENCY ANEMIA AND GROWTH IN BREASTFED INFANTS: HOME-MADE VS COMMERCIAL
}

\author{
Roedi Irawan, Nur Aisiyah Widjaja, Meta Herdiana Hanindita \\ Department of Child Health, Faculty of Medicine, Airlangga University/Dr. Soetomo Hospital, Surabaya, Indonesia
}

\section{ABSTRACT}

\begin{abstract}
After approximately 6 months of age, term breastfed infants are increasingly depend on other sources of iron to avoid iron deficiency anemia, due to the depletion of the low concentration of iron in human milk. The appropriate complementary feeding must include a balance composition of foods containing an adequate amount of macro- and micronutrients to avoid iron deficiency anemia. This study aimed to compare the risk of iron deficiency and growth in breastfeed infants receiving commercial fortified complementary foods or home-made. A cross-sectional study was held on April-June 2016 to evaluate infants aged 6-24 months with breast feeding intake for 6 month of life. Complementary feeding practices were determined by questionnaire; an unquantified food frequency and feeding practices questionnaire was used to determine usual food intake. Biochemical assessment of haemoglobin (Hb), serum ferritin (SF) and serum iron (SI) level were measured. Anthropometric were assessed using WHO Child Growth Standard 2005. Statistical analysis used were Chi-square Test. Thirty eight infants were enrolled, mean age of 16.2 (SD 10.5) months. 17 infants consumed commercial complementary foods and 21 infants use home-made. Infants with home-made had lower Hb level, SF and SI than those receiving commercial complementary food, and had higher risk of underweight, stunted and wasted. Infants with homemade complementary food had lower haemoglobin, serum feritin and serum iron levels than those in fortified complementary food $C F$; and a higher risk of stunted and wasted than children with commercial fortified CF.
\end{abstract}

Keywords: Iron deficiency anemia; complementary foods; breastfeed infant; growth

\section{ABSTRAK}

Setelah kurang lebih 6 bulan, bayi yang mendapat ASI semakin tergantung pada sumber zat besi lain untuk menghindari anemia defisiensi besi, karena menipisnya konsentrasi rendah zat besi dalam ASI. Pemberian makanan pendamping yang tepat harus mencakup komposisi makanan yang seimbang yang mengandung jumlah makro dan mikro yang cukup untuk menghindari anemia defisiensi besi. Penelitian ini bertujuan untuk membandingkan risiko kekurangan zat besi dan pertumbuhan pada bayi menyusui yang menerima makanan pendamping yang diperkaya secara komersial atau buatan sendiri. Sebuah studi cross-sectional diadakan pada bulan April-Juni 2016 untuk mengevaluasi bayi berusia 6-24 bulan dengan asupan menyusui selama 6 bulan kehidupan. Praktik pemberian makanan pelengkap ditentukan dengan kuesioner; kuesioner frekuensi makan dan praktik pemberian makan yang tidak dikenal digunakan untuk menentukan asupan makanan biasa. Penilaian biokimiawi kadar hemoglobin (Hb), serum ferritin (SF) dan serum besi (SI) diukur. Antropometri dinilai menggunakan Standar Pertumbuhan Anak WHO 2005. Analisis statistik yang digunakan adalah Uji Chi-square. Tiga puluh delapan bayi terdaftar, usia rata-rata 16,2 (SD 10,5) bulan. 17 bayi mengkonsumsi makanan pelengkap komersial dan 21 bayi menggunakan buatan sendiri. Bayi dengan buatan rumah memiliki kadar Hb, SF, dan SI yang lebih rendah daripada mereka yang menerima makanan komplementer komersial, dan memiliki risiko lebih rendah mengalami kekurangan berat badan, terhambat dan terbuang. Bayi dengan makanan komplementer buatan sendiri memiliki kadar hemoglobin, serum feritin, dan zat besi serum yang lebih rendah dibandingkan bayi dengan CF makanan komplementer yang diperkaya; dan risiko yang lebih tinggi terhambat dan terbuang dibandingkan anak-anak dengan CF komersial yang diperkaya.

Kata kunci: Anemia defisiensi besi; makanan pelengkap; bayi menyusui; pertumbuhan

Correspondence: Roedi Irawan, Division of Nutrition and Metabolic Disease, Departement of Child Health, Dr. Soetomo Hospital, Surabaya, Indonesia. Phone: +62 818-377-411. E-mail: roedi.dr.rsds@gmail.com

pISSN:2355-8393 • eISSN: 2599-056x • doi: http://dx.doi.org/10.20473/fmi.v55i2.14337

- Fol Med Indones. 2019;55:112-116• Received 16 Jun $2018 \bullet$ Accepted 27 Dec 2018

- Open access under CC-BY-NC-SA license • Available at https://e-journal.unair.ac.id/FMI/

\section{INTRODUCTION}

WHO recommended that infants should be exclusively breastfed for the 6 month of life before the introduction of complementary foods (UKK Nutrisi dan Penyakit
Metabolik 2015). Breast milk is an ideal food for young infants because of its unique nutrient profile. However, breast milk alone may lead to insufficiencies of some nutrients such as iron, zinc, vitamin $\mathrm{K}$ and vitamin $\mathrm{D}$ after a certain age (Mok et al 2017). After 6 month, term 
and breastfed infants needs another resources of iron to avoid iron deficiency because of the depletion of iron for rapid growth and low content of iron in breast milk (Kleinman 2009). Complementary foods are required to meet the macro- and micronutrient requirements (Solomon 2015).

Complementary feeding is defined as providing nutrient-containing foods or liquids along with human milk (or infant formula) and do not displace human milk or infant formula (WHO 1998). To meet the gap of breast milk nutritional decrease of macro- and micronutrients, good quality of complementary feeding are needed. This complementary food should include a balance composition of foods containing adequate amount of macro and micronutrients, especially iron, to avoid iron deficiency anemia.

In developing country iron deficiency anemia is a common problem, with infant and young child aged 0-5 years are a special risk group (IDAI 2011). The prevalence of iron deficiency in breastfed baby without iron supplementation is high. Iron deficiency in children mostly caused by low intake of iron in complementary foods and rapid growth at the first years of life.

More than $90 \%$ of iron requirements during complementary feeding period of breastfed infant must be provides by complementary foods. Strategies for achieving adequate iron intakes include the use of fortified complementary foods, iron-fortifed formulas, foods rich of bioavailable iron such as meat or supplements (Solomon 2015).

Both home-made and commercial complementary foods are equally acceptable alternatives for infant feeding (Kleinman 2009). Studies established from industrialized countries show high usage of commercially prepared complementary food in infants up to 9 months of age showed high levels of sodium and sugar, and tend to be a consistent texture and appearance (Mok et al 2017). However commercial complementary food provides iron which is needed by infants to enhance iron deficiency anemia caused by rapid growth. Meanwhile home-made complementary food provides a broader range of different flavors and textures which is affect the development of diet diversity, nutrient intakes and quality of infant growth (Mok et al 2017).

In Indonesia, most home-made complementary feeding could not meet the gap of nutrient requirements (UKK Nutrisi dan Penyakit Metabolik 2015). This study aimed to compare the risk of iron deficiency and growth in breastfeed infants to complementary feeding regimens that provide iron from fortified complementary food or home-made complementary foods in breastfed infants aged 6-24 months.

\section{MATERIALS AND METHODS}

This study is a cross-sectional, held on April-June 2016 to evaluate infants aged 6-24 months with breast feeding intake for 6 month of life. Complementary feeding practices were determined by questionnaire; an unquantified food frequency and feeding practices questionnaire was used to determine usual food intake. Biochemical assessment of haemoglobin ( $\mathrm{Hb})$, serum ferritin (SF) and serum iron (SI) level were measured. Anthropometric measurement was established to identify growth pattern of the infants using WHO child growth standard to assess growth of the infants. Statistical analysis used in this study was Chi-square Test.

\section{RESULTS}

Thirty eight infants were enrolled in this study, with 17 female and 11 male, aged 6-24 months old (mean age 16.2, $\mathrm{SD}=10.5$ ) and gestational age 6 infants pretem and 32 infants aterm. 28 infants got breast feeding exclusively, while 10 infants got beast milk for 4 month. After 6 month of life, 16 infants got both of breast milk and formula milk along with CF. Time of introduction CF mostly started at 6 month (33 infants) and the rest (5 infants) started at 7 month of age. All infants enrolled this study started accepting complementary feeding at the age of 6-7 month old.

This study revealed that 17 infants consume fortified complementary foods, and 21 infants consume homemade. The diversity of both home-made and commercial complementary foods are summarized at Table 1. Infants with home-made complementary food tend to have lower biochemical measure of $\mathrm{Hb}, \mathrm{SF}$ and SI than the infants consumed commercial complementary food, suggested that infants receiving home-made complementary food were higher risk to have iron deficiency anaemia (IDA) than infants with commercial fortified complementary food. Biochemical measurements of $\mathrm{Hb}, \mathrm{SF}$ and SI of infants with fortified complementary food and home-made complementary food are presented in Table 2.

Anthropometric measurements showed that children receiving home-made complementary foods had higher incidence than those receiving commercial one $(18.18 \%$ vs. $5.81 \%$ ). The incidence of wasted also higher in children with home-made complementary food than those receiving commercial (31.82\% vs. $17.65 \%)$. 
Anthropometric measurements of the infants are summarized at table 3 . There was a correlation between home-made CF and Weight for age (Z-score) with Odd
Ratio 4.91 (95\% CI 0.16 to 0.17 ) even statistically not significant.

Table 1. Diet diversity in 38 infants for accepting complementary feeding

\begin{tabular}{lc}
\hline \multicolumn{1}{c}{ Complementary foods } & infants \\
\hline Carrot+BM; Banana+BM; Vegetable/Fruit+BM; Maize porridge+BM; Gasol + BM & 1 \\
Carrot+BM; Vegetable/fruit+BM; Gasol + BM & 1 \\
Gasol* + BM & 1 \\
Carrot+BM; Commercial iron fortified porridge & 1 \\
Maize porridge+BM & 4 \\
Miscellaneous (rice, carrot, spinach, chicken, beef) & 1 \\
Banana+BM & 4 \\
Vegetable/fruit+BM & 2 \\
Maize porridge + BM; commercial Iron fortified porridge & 1 \\
Carrot + BM; Vegetable/fruit + BM & 2 \\
Carrot + BM; banana + BM & 1 \\
Commercial iron fortified porridge & 8 \\
Carrot +BM; maize porridge + BM & 1 \\
Banana + BM; Commercial iron fortified porridge & 1 \\
Carrot + BM; Commercial Iron fortified porridge & 3 \\
Vegetable/fruit + BM; Commercial Iron fortified porridge & 2 \\
Banana + BM; maize porridge + BM & 1 \\
Vegetable/fruit + BM; Maize porridge + BM; Gasol +BM & 1 \\
Vegetable/fruit + BM; maize porridge + BM & 1 \\
Carrot+BM; vegetable/fruit+BM; Gasol+BM & 1 \\
Vegetable/fruit+BM; maize porridge + BM; commercial iron fortified porridge & 1 \\
\hline Note: BM = Breast milk; *Gasol is a brand of flour produced by organic farming & \\
\hline
\end{tabular}

Table 2. Biochemical measurements of $\mathrm{Hb}, \mathrm{SF}$ and SI of infants with fortified $\mathrm{CF}$ and home-made $\mathrm{CF}$

\begin{tabular}{lccc}
\hline \multicolumn{1}{c}{ Biochemical measurements } & $\begin{array}{c}\text { Commercial Fortified } \\
\text { CF }\end{array}$ & Home-made CF & $\begin{array}{c}\text { Reference range value to } \\
\text { diagnose IDA }\end{array}$ \\
\hline Haemoglobin $(\mathrm{Hb})$ in $\mathrm{mg} / \mathrm{dL}$ & $16.38(\mathrm{SD}=21.0)$ & $10.9(\mathrm{SD}=1.35)$ & Below 11.0 \\
Serum Feritin $(\mathrm{SF})$ in $\mu \mathrm{g} / \mathrm{l}$ & $58.9(\mathrm{SD}=34.3)$ & $49.7(\mathrm{SD}=21.7)$ & Below $12 \mu \mathrm{g} / \mathrm{L}$ \\
Serum Iron $(\mathrm{SI})$ in $\mu \mathrm{g} / \mathrm{l}$ & $60.1(\mathrm{SD}=28.3)$ & $58.2(\mathrm{SD}=23.2)$ & $50-120 \mu \mathrm{g} / 1$ \\
\hline
\end{tabular}

Table 3. Anthropometric measurements of children receiving home-made and commercial fortified complementary food

\begin{tabular}{lcc}
\hline & Home-made complementary food & Commercial complementary food \\
\hline Weight for Length (Z-score) & & $13(76.47 \%)$ \\
Normal & $14(63.64 \%)$ & $3(17.65 \%)$ \\
Wasted & $7(31.82 \%)$ & $1(5.88 \%)$ \\
Severe wasted & $1(4.54 \%)$ & \\
Length for Age (Z-score) & & $16(94.12 \%)$ \\
Normal & $17(77.27 \%)$ & 0 \\
Stunted & $4(18.18 \%)$ & $1(5.88 \%)$ \\
Severe stunted & $1(4.55 \%)$ & - \\
Weight for Age (Z-score) & & $11(64.71 \%)$ \\
Over weight & $1(4.54 \%)$ & $5(29.41 \%)$ \\
Normal & $14(63.64 \%)$ & $1(5.88 \%)$ \\
Under weight & - & \\
Severely under weight & $7(31.82 \%)$ & \\
\hline
\end{tabular}




\section{DISCUSSION}

Infants consume home-made complemetary tend to have a mild iron deficiency anemia due to the low of haemoglobin concentration $(<11 \mathrm{mg} / \mathrm{dL})$. SF is a sensitive parameter for the assessment of iron stores in healthy subjects; $1 \mu \mathrm{g} / \mathrm{L}$ of SF corresponds to 8 to 10 $\mathrm{mg}$ of available storage iron. This study suggested that the dietary iron intake in home-made CF couldn`t meet the gap of iron requirement for infant and iron stores of infants start to deplete at about 6 months of age, leaving the infants at high risk of iron deficiency and iron deficiency anemia. This is especially true among exclusively breastfed infant due to low concentration of iron in breast milk and inadequate intake (RDA of iron for infant age 7-12 month old is $11 \mathrm{mg} /$ day and 7 $\mathrm{mg}$ /day for toddler age 1 to 3 years).

Most of infants in this study had breast milk along with complementary food which is low in iron uptake. Prell an Koletzko (Prell and Koletzko, 2016) stated that infant complementary foods should include iron derived from meat, as well as fish once or twice a week. Followon formulae should only be given once the child is taking complementary feeding. This suggestion is reasonable because human milk is relatively low in iron, while follow-on formulae fortified with iron although it is less of bioavailability. AAP section on breast feeding and ACOG (ACOG \& AAP 2014) also recommended that complementary foods should be fortified with iron or pureed meat to prevent iron deficiency anemia at 6 month of old, or iron drops $1 \mathrm{mg} / \mathrm{kg} / \mathrm{day}$. Iron fortified cereal has a less bioavailable but still a moderate sources of iron.

Qasem and Friel (2015) also suggested meat as the first choice of complementary food due to meat is a good source of protein, bioavailable iron and zinc as well as vitamins B6 and B12 and recommended as an appropriate early complemetary foods (Krebs 2007, Hambidge et al 2011).

Local complementary foods in Asia are mainly cerealbased, such as fruits (mashed bananas, boiled and mashed apples and other seasonal fruits such as papaya given to infants after mashed or mixed with cream or milk), vegetables are given after fruits by boiling and mashed in a blender and strained such as carrots or pumpkins, staple flour such as rice or wheat used to give as the first solid foods (Uvere \& Ene-Obong, 2013). The typical unfortified plant-based cereal may pose a risk of iron and zinc deficiency if consumed alone without supplements (WHO 1998) due to being a poor source of iron.
In developing cuntries, cereal grains or starchy roots and tubers are common early foods offered to infants (Krebs 2007) due to its affordability. Shams et al (2016) stated that grains such as rice are considered as the best food for starting complementary feeding. In Indonesia, most home-made complementary foods are lack sufficient quantities of iron, zinc and calcium, niacin and thiamin (Fahmida \& Santika 2016).

Banana and rice flour mixed with pumping/expressed breast milk are the major ingredient for Indonesian complementary foods. Both of those ingredients able to fill energy requirement of infant, but not with protein, iron and zinc requirement. Those two ingredients (rice flour and banana) are low of protein, iron (only $0.3 \mathrm{mg}$ of iron in banana and $0.1 \mathrm{mg}$ in rice flour) and zinc (UKK Nutrisi dan Penyakit Metabolik 2015).

The fortification of low nutrient density foods have been assessed to be adapted as a strategy to tackle the problem of micronutrients deficiency and malnutrition in the developing countries (Qasem \& Friel 2015). Iron fortified cereal has become an important vehicle to meet iron needs of the growing infant to prevent iron deficiency anemia in Canada (Friel et al 2009, Faber et al 2005) studied the effect of fortified maize-meal on anemia evidence in childhood and revealed that fortified maize-meal porridge reduces the incident of iron deficiency anemia in South Africa from $45 \%$ to $17 \%$. This means that the fortification strategies quite effective to reduce IDA incident in community. This strategy is important to reduce micronutrient malnutrition in childhood iron deficiency (Uvere \& Ene-Obong 2013).

Stunting is defined as a height that is more than two standard deviations below the World Health Organization (WHO) Child Growth Standards median 3. Stunting is a condition that results from prolonged inadequate food intake or from recurrent episodes of illness (WHO 2006). It is a largely irreversible outcome of inadequate nutrition and repeated bouts of infection during the first 1000 days of a child's life (Weise 2017).

A child whose weight is more than 2 standard deviations below the WHO reference median is referred to as wasted or too thin. This condition may reflect a recent period of inadequate food intake or a recent episode of illness (WHO 2006).

The most effective interventions for preventing stunting and wasting during the complementary feeding period by improving the quality of children's diet. Evidence suggests that greater dietary diversity and the consumption of foods from animal sources are associated with improved linear growth (Weise 2017). 
Meat consumed as complementary food is associated with greater linear growth without excessive gain in adiposity in breastfed infants (Tang and Krebs, 2014). A study conducted by Iannotti et al., (2017) revealed eggs intervention increased length-for-age $\mathrm{z}$ score by 0.63 and weight-for-age $\mathrm{z}$ score by 0.61 , reduced prevalence of stunting $(47 \%)$ and underweight $(74 \%)$.

\section{CONCLUSION}

Infants with home-made complementary food have lower haemoglobin, serum feritin and serum iron levels than those with commercial complementary food, and also had a higher risk of stunted and wasted than children with commercial complementary food.

\section{REFERENCES}

ACOG, AAP (2014). Breastfeeding Handbook for Physicians in New York. 2nd Ed. New York, AAP and ACOG, p 260-261

Faber M, et al (2005). Effect of a fortified maize-meal porridge on anemia, micronutrient status, and motor development of infants', American Journal of Clinical Nutrition 82, 1032-1039

Fahmida U, Santika O (2016). Development of complementary feeding recommendations for 12-23month-old children from low and middle socioeconomic status in West Java, Indonesia: Contribution of fortified foods towards meeting the nutrient requirement. British Journal of Nutrition 116, S8-S15

Friel JK, et al (2009). Complementary food consumption of Canadian infants. The Open Nutrition Journal 3, 11-16

Hambidge MK, et al (2011). Evaluation of meat as a first complemenatry food for breastfed infants: impact on iron intake and growth. Nutr Rev 69, 1-9

Iannotti LL, et al (2017). Eggs in early complementary feeding and child growth: A randomized controlled trial. Pediatrics 140, e20163459

IDAI SA (2011). Suplementasi besi untuk anak.

Kleinman RE (2009). Pediatric nutrition handbook. 3rd ed. Edited by R. Kleinman. Available from: http://agris.fao.org.ezproxy.library.wisc.edu/agrissearch/search.do?recordID=US19950105675.

Krebs N (2007). Meat as an early complementary food for infants: Implications for macro- and micronutrient intakes. Nestle Nutrition Workshop Series: Pediatric Program 60, 221-229

Mok E, et al (2017). Diet diversity, growth and adiposity in healthy breastfed infants fed homemade complementary foods. International journal of obesity 41, 776-782

Prell C, Koletzko B (2016). Breastfeeding and complementary feeding. Deutsches Arzteblatt International 113, 435-444

Qasem W, Friel J (2015). The recommended first complementary foods: A review of the literature. Journal of Pediatrics \& Neonatal Care 2, 1-9

Shams N, Mostafavi F, Hassanzadeh A (2016). Determinants of complementary feeding practices among mothers of 6-24 months failure to thrive children based on behavioral analysis phase of PRECEDE model. J Educ Health Promot 5, 1-7

Solomon N (2015). Iron deficiency and other nutrient deficiency. In Koletzko B, Cooper P, Makrides M (eds) Pediatric Nutrition in Practice. 2nd revise. Munich, Karger, p 1-305

Tang M, Krebs NF (2014). High protein intake from meat as complementary food increases growth but not adiposity in breastfed infants: A randomized trial. American Journal of Clinical Nutrition 100, 13221328

UKK Nutrisi dan Penyakit Metabolik (2015). Rekomendasi praktik pemberian makan berbasis bukti pada bayi dan batita di Indonesia untuk mencegah malnutrisi. Badan Penerbit IDAI

Uvere PO, Ene-Obong HN (2013). Complementary local foods for infants in developing countries, Nutrition in infancy 1

Weise A (2017). WHA Global Nutrition Targets 2025: Stunting policy brief

WHO (1998). Complementary feeding of young children in developing countries?: A review of current scientific knowledge. World Health Organization (WHO)

WHO (2006). The new WHO child growth standards, WHO. Geneva, WHO 